\title{
The Determinants of Indonesian Railway OnlineTicketing Services in Indonesia
}

\author{
Aditya Wardhana ${ }^{1}$, Budi Rustandi Kartawinata ${ }^{2}$ \\ Department of Business Administration, Faculty of Communcation and Business, Telkom University, Bandung, Indonesia
}

\begin{abstract}
The aim of the research examined the factors that forming the quality of online services ticketing at PT KAI in Indonesia. In this research using factor analysis, factors that forming the quality of online services ticketing on PT KAI consisting of navigability, playfulness, information quality, trust, personalization, responsiveness, efficiency, system availability, and privacy in general show good condition.The dominant factor in forming the quality of online services ticketing on PT KAI is information quality.
\end{abstract}

Keywords: quality of online services ticketing, railway transportation, factor analysis

\section{Introduction}

Transportation had enormous influence in the economic aspect. Economy growing toward globalization need its high mobility, so people are getting jelly in choosing means of transport will be used. Many companies transportation offer and try to seize interest consumers to use products or services offered by of a transportation company.

Schnaars in Tjiptono (2011), basically the purpose of a business is to create the consumers who are satisfied. Satisfied consumer will be achieved when the quality products or services given by a company in conformity with the consumer's wishes because the quality of services very depends on who and how that service given.

PT Kereta Api Indonesia (Persero) or later called KAI is one of state-owned company which are engaged in the mainland railway transport services in order to facilitate the displacement people or goods in mass in order to support national development. KAI provides transportation for passengers in Java, South Sumatra, West Sumatra, and North Sumatra. Train appear to reach by the people in Indonesia. Fluctuations the rise and fall the number of trains passengers can be seen in Table 1 .

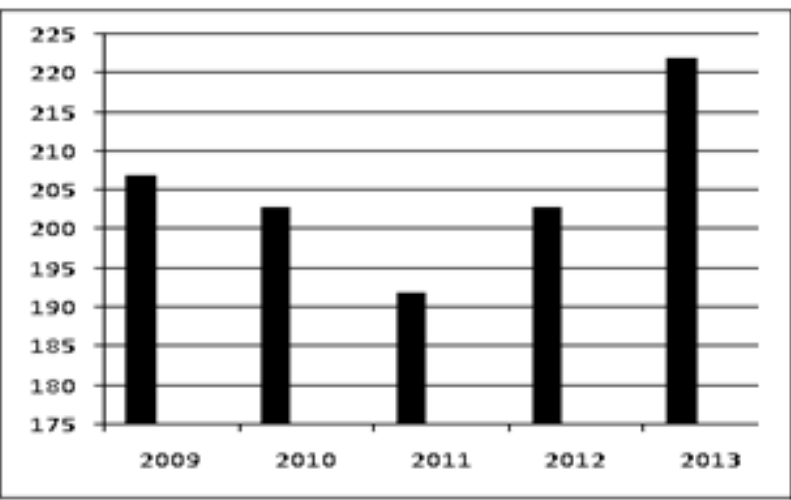

Table 1: Total Passangers of PT.KAI for Year 2009-2013 (In Million)

Source:Annual Report KAIfor The End of Year 2013
The government showed concern in focusing on service to train users as this demonstrates on the regulation of tickets in the act of Number 23/2007 about railway transportatio. KAI run the online ticketing system (online reservation ticket to passengers who will use the railway services). With the online ticketing system, the ticket was sold through the external channel company as in agent, this online banking payment and banks atm had become partner with. Research conducted by Septianita, Winarno, and Arif (2014) said that the quality of the system, the quality of information, and the quality of service, that they all fit a positive influence on the users satisfaction. According to Jayanthi, Ramya, \&Raja (2014), companies that moved in the services sector growing by the existence of advanced technology in the world of business like the internet. Profit made from electronic ticket on merit train transportation of the other is promotion online, reduction employees sale or ticketing, reduce the print tickets conventional, reduce the cost of purchases tickets, and save time for those. Electronic ticket had some limits, first, many those who do not use the internet. Second, a certain amount of time and hardship of use the electronic ticket were actually might be important, especially for internet users who lacking the experience.

Based on the discussion which have been explained earlier, then the researcher interested to do research on analysisof the factors that determine the quality of online ticketing services on railway transportation in Indonesia, so that this research entitled "The Determinants of Railway OnlineTicketingServices in Indonesia".

\section{Review of Literature}

Electronic Service Quality: According toParasuraman et al (2005) said that e-service quality is defined broadly to encompass all phases of a customer's interactions with a website: the extent to which a website facilitates efficient and effective shopping, purchasing, and delivery.Based on a number of literature reviews the existing showed that a latest study found a lot of difference dimensions was used to measure the quality of services electronic in various different fields as shown on Table 2 . 


\section{International Journal of Science and Research (IJSR) \\ ISSN (Online): 2319-7064}

Index Copernicus Value (2013): 6.14 | Impact Factor (2015): 6.391

Table 2: LiteraturReviews of Electronic Service Dimensions

\begin{tabular}{|c|c|c|}
\hline Author(s) & Dimensions & Context \\
\hline Dabholkar (1996) & Speed delivery,ease of use, realiability, conformity, and \\
Control. & E-Service \\
\hline Szymanski \&Hise (2000) & Online conformity, information ofproduct, web design, andfinancial secure. & E-Satisfaction \\
\hline Zeithaml, et al. (2000) & $\begin{array}{c}\text { Access, ease ofnavigation, efficiency, flexibility, reliability, personalization, } \\
\text { privacy, responsiveness, assurance, aesthetics, web and price knowledge. }\end{array}$ & E-service \\
\hline Kaynama\& Black (2000) & $\begin{array}{c}\text { Content, access, navigation, design, response, background andpersonalization. } \\
\text { Yoo\&Donthu (2001) }\end{array}$ & $\begin{array}{c}\text { Elektronik } \\
\text { Retailing }\end{array}$ \\
\hline Barnes \&Vidgen (2002) & Ease of use, aesthetics design, speed processing and security. & Website Quality \\
\hline Liljander, et al. (2002) & Usability, desain, informasi, trust and empathy & Website Quality \\
\hline Janda, et al. (2002) & Web design and content,trust, empathyand security & E-Quality \\
\hline $\begin{array}{c}\text { Zeithaml, et al. (2002) } \\
\text { Performance, access, security, sensationand information }\end{array}$ & $\begin{array}{c}\text { Elektronik Retailing } \\
\text { Service }\end{array}$ \\
\hline $\begin{array}{c}\text { Wolfinbarger\&Gilly } \\
\text { (2003) }\end{array}$ & Fulfillment/reliability, website design, customer servicesand privacy. & E-service \\
\hline
\end{tabular}

Source: Tjiptono (2011)

Online Ticketing: Online ticketing service (online ticket reservation) is a web-based service which is one of the examples of e-commerce. According to Turban (2004), ecommerce is the process of buying, selling, transfer or exchange of products, services and information via computer networks including the internet.According to Koppius et al (2005) electronic ticket is a system the sales of tickets online in this context is train tickets. The sales of tickets online that allows customers to be able to do the purchase without have to visit the locket train or agents of the ticket sales.Consumers needing only to an internet connection to be connected with a system of ticket sales the intended online, that way the customer can gather information about the will depart, seating configuration, do the booking tickets, buy a ticket on the whole those activities can be done by using an internet connection.In addition, consumers also able to make the payments directly at the website the through the transfer through a bank referred or through credit card.After the the payment is received, consumers will receive code booking a ticket redeemable at the printing press tickets machine in station to get tickets railway travel.So, people did not have to a waste of time to go to place the ticket sale, visit travel agents who sells tickets only to do the process of purchasing.Previous research conducted by Septianita, Winarno, and Arif (2014) stating that the quality of system, the quality of information and the quality of services all have leverage positive on satisfaction users.Batagan, Pocovnicu, and Capisizzu (2009)said that eservice offer speed, efficiency, flexibility and innovation to the user.Parasuraman, Zeithaml, and Malhotra (2005) said that e-service quality has links with perceived value and loyalty intentions.Li, Liu , and Suomi (2009) said that the perception the quality of traditional services based on evaluation interaction between providers and customers, perception of the quality of online services was commonly based on the evaluation of interactions between customers and a user interface.Every online providers standard uses interface and technology for their customers.Jain \&Kumar (2011) said that dimension e-service quality yield four the main factor of that is efficiency, responsiveness, privacy, security and reliability.Based on the research, privacy and security is strongest dimensions followed by efficiency, responsiveness, privacy and reliability.In addition, manager has got to build strategy that is appropriate to increase the speed and availability website 24 hours. Kandampullyand Nusair (2008) stated that there are some antecedent to customer satisfaction in the use of online travel services namely: navigability, playfulness, quality of information, trust, personalization, and responsiveness.Jain \&Kumar (2011) said that dimension e-service quality yield four the main factor of that is efficiency, responsiveness, privacy, security and reliability. While Zeithaml (2002) and Parasuraman et al (2005) in Jain\&Kumar (2011), has suggested there are four dimension in electronic the quality of service that is efficiency, fulfillment, system availability, and privacy.The quality of services online ticketing in this research using 10 variables i.e. navigability, playfulness, quality information, trust, personalization, responsiveness, efficiency, system availability, and privacy.Research paradigm can be seen from next figure. 


\section{International Journal of Science and Research (IJSR)}

ISSN (Online): 2319-7064

Index Copernicus Value (2013): 6.14 | Impact Factor (2015): 6.391

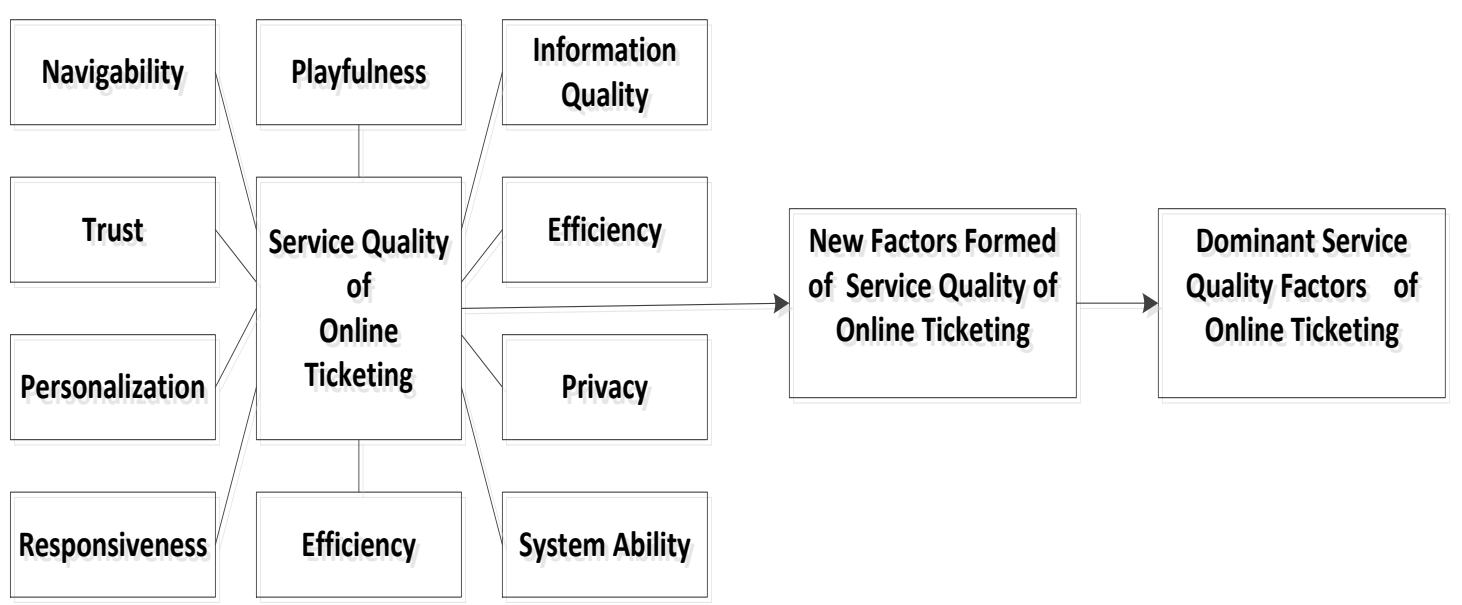

Figure 1: Research Framework

Based on the reserach framework and problems research, it can be formulated hypothesis as follows: navigability, playfulness, information quality, trust, personalization, responsiveness, efficiency, system availability, and privacy form the quality of services online ticketing.

\section{Research Methods}

A method of this research is quantitative research methodology.According to Sugiyono (2014) a method of quantitative research can be defined as a method of research based on the philosophy of positivism, used to scrutinize in the population or a given sample of, data collection using research instruments, data analysis is quantitative/statistics, with the aim of test the hypothesis that has been set.The type of research is desktiptive research.Descriptive analysis done to review and been able to explain characteristic variables investigated in a situation. The purpose of this analysis is given a history of research or to describe aspects relevant to the attention from the perspective of someone, organization, orientation industry, or other (Sekaran, 2010). The scale used in this research was ordinalscale. Ordinal is scale basis of ranking in which the given to an object to identify degrees relatively characteristic of objects. So made it possible for us to determine whether an object have characteristic more or characteristic of less than some other objects (Malhotra, 2010).Based on the formulation of problems so variable to be used is variables form the quality of services online ticketing consisting of variable navigability, playfulness, information quality, trust, personalization, responsiveness, efficiency, system availability, and privacy.

\section{Sampel Selection}

According to Malhotra (2010), sample is sub group element of the population chosen to participate in the study.In this research, sample taken from the customers ever held a transaction use the service of online reservation ticket in reservations train ticket in Indonesia, consumers used as population research were 88.691 .733 consumers per year 2013 for all the purpose of the train (source: internal data KAI for year 2013). Based on the Slovinformula, the sample of the minimum obtained was as many as 400 respondents.

\section{Result}

Data analysis was cunducted by factor analysis. The constructs were, also tested for validity and reliablity and were found to be relatively sound. Then, the proposed model was tested using SPSS.

Table 3: Total Variance Explained

\begin{tabular}{|c|c|c|c|c|c|c|}
\hline \multirow{2}{*}{ Component } & \multicolumn{3}{|c|}{ Initial Eigenvalues } & \multicolumn{2}{c|}{ Extraction Sums of Squared Loadings } \\
\cline { 2 - 7 } & Total & $\begin{array}{c}\text { \% of } \\
\text { Variance }\end{array}$ & $\begin{array}{c}\text { Cumulative } \\
\%\end{array}$ & Total & $\begin{array}{c}\text { Cumulative } \\
\text { Variance }\end{array}$ & 20.3 \\
\hline 1 & 2.17653 & 20.3 & 20.3 & 2.17653 & 20.3 & 37.9 \\
\hline 2 & 1.98331 & 17.6 & 37.9 & 1.98331 & 17.6 & 49.7 \\
\hline 3 & 1.88445 & 11.8 & 49.7 & 1.88445 & 11.8 & 60.4 \\
\hline 4 & 1.70236 & 10.7 & 60.4 & 1.70236 & 10.7 & 70.3 \\
\hline 5 & 1.67492 & 9.9 & 70.3 & 1.67492 & 9.9 & 89.2 \\
\hline 6 & 1.41418 & 8.9 & 79.2 & 1.41418 & 8.9 & 9.8 \\
\hline 7 & 1.62761 & 7.8 & 87.0 & 1.62761 & 6.7 & 93.7 \\
\hline 8 & 1.39638 & 6.7 & 93.7 & 1.39638 & 6.7 & 100.0 \\
\hline
\end{tabular}


International Journal of Science and Research (IJSR)

ISSN (Online): 2319-7064

Index Copernicus Value (2013): 6.14 | Impact Factor (2015): 6.391

Table 4: Component Factor

\begin{tabular}{|c|c|}
\hline \multirow{2}{*}{ Atributes } & Component \\
\cline { 2 - 2 } & $\mathbf{1}$ \\
\hline navigability & .663 \\
\hline playfulness & .458 \\
\hline information quality & .858 \\
\hline trust & .682 \\
\hline personalization & .673 \\
\hline responsiveness & .570 \\
\hline efficiency & .439 \\
\hline system availability & .793 \\
\hline privacy & .579 \\
\hline
\end{tabular}

\section{Conclusion}

Resumes of the research is that factors forming the quality of online services ticketing on KAI consisting of navigability, playfulness, information quality, trust, personalization, responsiveness, efficiency, system availability, and privacy in general show good condition. The dominant factor in forming the quality of online services ticketing on kai is information quality

\section{References}

[1] Batagan, L., Pocovnicu, A., and Capisizzu, S. 2009. EService Quality Management. Journal of Aplied Quantitative Methods, Vol. 4, No. 3, pp.372-380

[2] Jain, P., \& Kumar, N. 2011. Measurement of E-Service Quality: An Empirical Study on. Online Railway Ticket Reservation Website Service. The International Journal of Management and Marketing Research, Vol. 2, Issue 1,pp.22-38

[3] Jayanti, M., Ramya, S.S., \& Raja, M. 2014. A Study on Awarness and Usage of E-Tickets in Railways. The International Journalof Business\& Management, Vol. 2, Issue 10, pp.31-34

[4] Malhotra, N. 2010. Marketing Research: An Applied Orientation. New York; Pearson Education.

[5] Kandampully, J., and Nusair, K. 2008. The Antecedents of CustomerSatisfaction with Online Travel Services: A Conceptual Model. European Business Review. Vol. 20, No. 1, pp.4-19

[6] Koppius, O., Speelman, W., Stulp, O., Verhoef, B., van Heck, E. 2005. Why are customers coming back to buy their airline tickets online? Theoretical explanations and empirical evidence. Proceedings of the 7th international conference on Electronic commerce, Xi'an, China, pp.319-326

[7] Li, H., Liu, Y., and Suomi, R. 2009. Measurement of EService Quality: An Empirical Study in Online Travel Services. ECIS Proceedings. paper 191.

[8] Parasuraman, A., Zeithaml, V.A., and Malhotra, A. 2005. E-S-Qual: A Multiple Item Scale for Assessing Electronic Service Quality. Journal of Service Research, Vol. 7, No. X, pp.1-21

[9] Sekaran, Uma.,\&. Bougie, Roger. 2010. Research Methods for Business. Southern Gate: John Wiley and Sons.

[10] Septiana, W., Winarno, W.A., and Arif, A. 2014. Effect System Quality, Information Quality, Service Quality of Rail Ticketing System (RTS) to User Satisfaction (Empirical Study at PT. KeretaApi Indonesia (Persero)
DAOP 9 Jember). JournalEkonomiBisnisdanAkuntansi, Vol.1, No.1, pp.53-56

[11] Sugiyono, (2014). MetodePenelitianManajemen. Bandung: Alfabeta.

[12] Tjiptono, Fandy.,Gregorius Chandra, andDadi Adriana. 2011. PemasaranStrategik. Yogyakarta: Andi

[13] Turban, E et al. 2004. Electronic Commerce 2004: A Managerial Perspective. Singapore: Prentice Hall. 